\title{
Characterization of AMBN I and II Isoforms and Study of Their $\mathrm{Ca}^{2+}$-Binding Properties
}

\author{
Veronika Vetyskova ${ }^{1,2}$, Monika Zouharova ${ }^{1,3}$, Lucie Bednarova ${ }^{1}$, Ondřej Vaněk ${ }^{4}($, \\ Petra Sázelová ${ }^{1}$, Václav Kašička ${ }^{1}{ }^{\circledR}$, Jiri Vymetal ${ }^{1}$, Jaroslav Srp ${ }^{1}{ }^{1}$, Michaela Rumlová ${ }^{5}$, \\ Tatsiana Charnavets ${ }^{6}$, Klara Postulkova ${ }^{1}$, Janne E. Reseland ${ }^{7}{ }^{\circledR}$, Kristyna Bousova ${ }^{1, *}$ \\ and Jiri Vondrasek ${ }^{1, *(1)}$ \\ 1 Institute of Organic Chemistry and Biochemistry of the Czech Academy of Sciences, Flemingovo nam. 2, \\ 16000 Prague, Czech Republic; veronika.vetyskova@uochb.cas.cz (V.V.); \\ monika.vargova@uochb.cas.cz (M.Z.); lucie.bednarova@uochb.cas.cz (L.B.); \\ petra.sazelova@uochb.cas.cz (P.S.); vaclav.kasicka@uochb.cas.cz (V.K.); jiri.vymetal@uochb.cas.cz (J.V.); \\ jaroslav.srp@uochb.cas.cz (J.S.); klara.postulkova@uochb.cas.cz (K.P.) \\ 2 Department of Biochemistry and Microbiology, University of Chemistry and Technology Prague, \\ Technicka 5, 16628 Prague, Czech Republic \\ 3 Second Faculty of Medicine, Charles University, V Uvalu 84, 15006 Prague 5, Czech Republic \\ 4 Department of Biochemistry, Faculty of Science, Charles University, Hlavova 2030/8, \\ 12840 Prague, Czech Republic; ondrej.vanek@natur.cuni.cz \\ 5 Department of Biotechnology, University of Chemistry and Technology Prague, Technicka 5, \\ 16628 Prague, Czech Republic; michaela.rumlova@vscht.cz \\ 6 Institute of Biotechnology of the Czech Academy of Sciences, Prumyslova 595, 25250 Vestec, Czech Republic; \\ chernt@ibt.cas.cz \\ 7 Department of Biomaterials, Institute of Clinical Dentistry, University of Oslo, 0317 Oslo, Norway; \\ j.e.reseland@odont.uio.no \\ * Correspondence: kristyna.bousova@uochb.cas.cz (K.B.); jiri.vondrasek@uochb.cas.cz (J.V.); \\ Tel.: +420-220-183-131 (K.B.); +420-220-183-267 (J.V.)
}

Received: 5 November 2020; Accepted: 3 December 2020; Published: 5 December 2020

\begin{abstract}
Ameloblastin (Ambn) as an intrinsically disordered protein (IDP) stands for an important role in the formation of enamel - the hardest biomineralized tissue commonly formed in vertebrates. The human ameloblastin (AMBN) is expressed in two isoforms: full-length isoform I (AMBN ISO I) and isoform II (AMBN ISO II), which is about 15 amino acid residues shorter than AMBN ISO I. The significant feature of AMBN-its oligomerization ability-is enabled due to a specific sequence encoded by exon 5 present at the $\mathrm{N}$-terminal part in both known isoforms. In this study, we characterized AMBN ISO I and AMBN ISO II by biochemical and biophysical methods to determine their common features and differences. We confirmed that both AMBN ISO I and AMBN ISO II form oligomers in in vitro conditions. Due to an important role of $A M B N$ in biomineralization, we further addressed the calcium $\left(\mathrm{Ca}^{2+}\right)$-binding properties of AMBN ISO I and ISO II. The binding properties of $\mathrm{AMBN}$ to $\mathrm{Ca}^{2+}$ may explain the role of AMBN in biomineralization and more generally in $\mathrm{Ca}^{2+}$ homeostasis processes.
\end{abstract}

Keywords: ameloblastin; biomineralization; oligomerization; calcium binding; intrinsically disordered protein (IDPs)

\section{Introduction}

Ameloblastin (Ambn; also known as amelin or sheatlin) is an enamel matrix phosphoprotein classified by computational and biophysical methods as an intrinsically disordered protein (IDP) [1-3]. 
Ambn with other ameloblasts-specific IDPs is important in biomineralization processes during enamel formation [4-6]. Interestingly, tooth enamel in vertebrates is the hardest known mineralized tissue [7]. The biomineralization is a complex process controlled by ameloblasts, which are the specific secretory cells responsible for the synthesis of enamel matrix proteins that control the process leading to the formation of enamel matrix [8]. In addition to Ambn, there are other Extracellular Matrix Proteins (EMPs) classified as IDPs involved in the mineralization process-amelogenin [9], tuftelin [10], and enamelin [11]. There are complementary proteases acting during mineralization; the most important are kallikrein-4 (KLK4) and enamelysin (MMP20) [12]. It is known that IDPs do not form a stable three-dimensional structure, neither elements of secondary structures (with some exception upon a dramatic change of environment [13]) nor their biological function is primarily dependent on interactions with other biomolecules [4]. However, some of the IDPs can adopt different structures upon a binding to their native partner. In such case, we describe these complexes as "fuzzy", as they can provide more options of binding between the interacting partners [4,14].

The sequence-based analysis of human ameloblastin (AMBN) according its chemical-physical properties implies an existence of two different parts of the protein. The N-terminal part (AMBN-Nterm) - about 220 amino acids residues long (spanning regions from exon 1 to exon 10) is neutral, enriched by proline-rich regions and a few short regions of hydrophobic amino acids. This suggests that these hydrophobic regions can act in AMBN-facilitated protein-protein interactions. The AMBN C-terminus (AMBN-Cterm) is highly charged, 225 amino acids residues long (spanning the regions from exon 10 to exon 13), and its total calculated charge is $-19.6[1,15-18]$. This finding clearly sets a distinction between both parts of the AMBN. Additionally, the AMBN-Cterm highly enriched by negatively charged amino acid residues may also act as a cation-binding proxy $[6,16]$. Mineralized tooth enamel is an inorganic structure composed of hydroxyapatite (HAP) crystals, which are formed by a saturated solution of $\operatorname{HAP}\left(\mathrm{Ca}_{10}\left(\mathrm{PO}_{4}\right)_{6}(\mathrm{OH})_{2}\right)[4,19,20]$. This raises the question of whether the negatively charged part of AMBN-the acidic AMBN-Cterm (unphosphorylated or phosphorylated)-may play a role in calcium $\left(\mathrm{Ca}^{2+}\right)$ binding and to what extent it may contribute to the oligomerization of AMBN and the biomineralization process.

The first supramolecular assemblies of enamel have been shown to be formed by specific proteinprotein interactions of proteins secreted by ameloblasts during the enamel formation process $[4,21,22]$ with a pivotal role of Ambn and Amel. It was proposed that this arrangement could be important for scaffolding suitable for the deposition of hydroxyapatite [22]. It was also shown experimentally that Ambn and Amel can co-assemble in a specific order facilitated by a tyrosyl-binding motif [22-24], promoting the formation of hetero-oligomers [2,4,21,22]. Interestingly, the AMBN itself exists only in oligomeric states, and their population is heterogeneous [2]. It was proved that the AMBN-specific oligomerization property is maintained by exon 5 , which is a 37 amino acid long region at the AMBN-Nterm $[1,2,25]$. Some residues of exon 5 that are evolutionarily conserved facilitate interaction with AMEL and also binding to a lipid membrane [24-26]. AMBN with deleted exon 5 (AMBN del E5) completely loses its ability to form oligomers and exists only in a monomeric form [2]. The exon 5 knock-out has a significant biological effect. The produced monomeric AMBN in the mice model causes structural abnormalities that result in an irregular formation of dental enamel [25]. Defects in the process of enamel development result in amelogenesis imperfecta [27].

Extracellular matrix proteins (EMPs) originated from a common ancestor and form an evolutionarily conserved family of Secretory Calcium-Binding Phosphoproteins (SCPPs). Most scientists today believe that they have enamel-only functions and are produced exclusively by secretory ameloblast cells [28]. However, the evolutionary divergence of EMPs $[28,29]$ indicates a discrepancy between the evolutionary appearance of the enamel and the divergence of the EMP. A possible explanation for this contrast is, as suggested by [30], that EMPs may initially be co-evolved for parallel functions, e.g., roles in general $\mathrm{Ca}^{2+}$ metabolism and/or its deposition in bone tissues explosion when $\mathrm{Ca}^{2+}$ storage has become an important evolutionary innovation [31]. 
Both Ambn ISO I and Ambn ISO II isoforms are evolutionary conserved and have been identified at the mRNA or cDNA level in human and three other mammalian species (Rattus rattus, Mus musculus, Sus scrofa domestica) [15,32-34]. The human AMBN is known to be expressed in most mammalian cells in two isoforms: AMBN ISO I and AMBN ISO II. The AMBN ISO II is 15 amino acids shorter than AMBN ISO I, and interestingly, these residues are the first amino acids of exon 6 at its very $\mathrm{N}$-terminus $[1,15,32]$. So, there is a question if due to the important role of exon 5 , the missing piece of the sequence of exon 6 could influence the oligomerization properties of the AMBN. Moreover, predicted phosphorylation sites at tyrosine or serine residues in this segment (YEYSLPVHPPPLPSQ) suggest important implications for both isoforms and their functions $[3,15,33]$. There is no information about the importance or different functions of both AMBN isoforms nor their different physical-chemical properties. In this study, we addressed properties of human AMBN ISO I and AMBN ISO II using a spectrum of biophysical methods, and the assessed ability of both isoforms to bind $\mathrm{Ca}^{2+}$ as one of the consequences of protein oligomerization.

\section{Results}

\subsection{AMBN ISO I and AMBN ISO II Belong to IDPS}

The circular dichroism (CD) spectra of AMBN ISO I (Figure 1A and Figure S1) were consistent with our previous AMBN characterizations [2]. The CD spectrum of AMBN ISO I was characterized by a negative maximum at $\approx 202 \mathrm{~nm}$ (Figure S1) accompanied by negative shoulder at $\approx 220 \mathrm{~nm}$. With the temperature increase, the $202 \mathrm{~nm}$ spectral band is red shifted, and its intensity decreases. This spectral change is accompanied by an intensity increase of the negative spectral band at $\approx 220 \mathrm{~nm}$. The observed spectral changes with an isosbestic point at $\approx 208 \mathrm{~nm}$ are typical for IDPs [35]. The overall low spectral intensity of CD spectra was in good agreement with our previous analysis [2], which was interpreted as a raising presence of $\beta$-structure elements.

The CD spectrum of AMBN ISO II has similar spectral shape as observed for AMBN ISO I, with a negative maximum at $203 \mathrm{~nm}$ and negative shoulder at $\approx 220 \mathrm{~nm}$ (Figure 1A and Figure S1). This spectral band is red shifted upon the increasing temperature accompanied by an increase of negative spectral band intensity at $\approx 220 \mathrm{~nm}$ similarly as AMBN ISO I. The corresponding isosbestic point was determined at $\approx 209 \mathrm{~nm}$.

The CD spectrum of AMBN del E5 is characterized by a negative maximum at $\approx 199 \mathrm{~nm}$ with a higher intensity than AMBN ISO I and AMBN ISO II (Figure 1A and Figure S1). The overall spectral changes together with the isosbestic point at $\approx 208 \mathrm{~nm}$ support our conclusion that AMBN del 5 is an IDP [35].

The CD spectra of AMBN ISO I and AMBN ISO II in $10 \mathrm{mM} \mathrm{Ca}^{2+}$ solution are in fact almost unchanged compared with the $\mathrm{Ca}^{2+}$-free solution. The spectral changes for AMBN ISO I and ISO II upon increasing temperature in the $10 \mathrm{mM} \mathrm{Ca}^{2+}$ solution do not provide clear localization of the isosbestic point. Interestingly, both proteins are dominantly populated by $\beta$-structure elements at $90{ }^{\circ} \mathrm{C}$, suggesting a high aggregation state. With return to the temperature at $20^{\circ} \mathrm{C}$, the $\mathrm{CD}$ spectra confirmed highly efficient reversible process. There are only small spectral differences observed, which could be assigned to the elevated presence of $\beta$-structure elements upon restoring initial conditions [2]. No spectral changes were observed for AMBN del E5 in the presence of $\mathrm{Ca}^{2+}$. The CD spectra temperature dependency of AMBN del E5 in $10 \mathrm{mM} \mathrm{Ca}^{2+}$ solution is almost the same as for AMBN del E5 in $\mathrm{Ca}^{2+}$-free solution, but the isosbestic point is red shifted to $210 \mathrm{~nm}$ (Figure S1). It can be concluded that AMBN del E5 behaves constantly as an IDP and this behavior is $\mathrm{Ca}^{2+}$ independent. [35].

To confirm the IDP character of all protein constructs (AMBN ISO I, AMBN ISO II, AMBN del E5) computational disorder prediction analysis by D2P2 (Database of Disordered Protein Predictions) was performed [36]. The results confirmed the IDP character of all studied proteins and did not reveal any significant differences between the AMBN ISO I and AMBN ISO II or AMBN del E5 (Figure S2, [36]). 


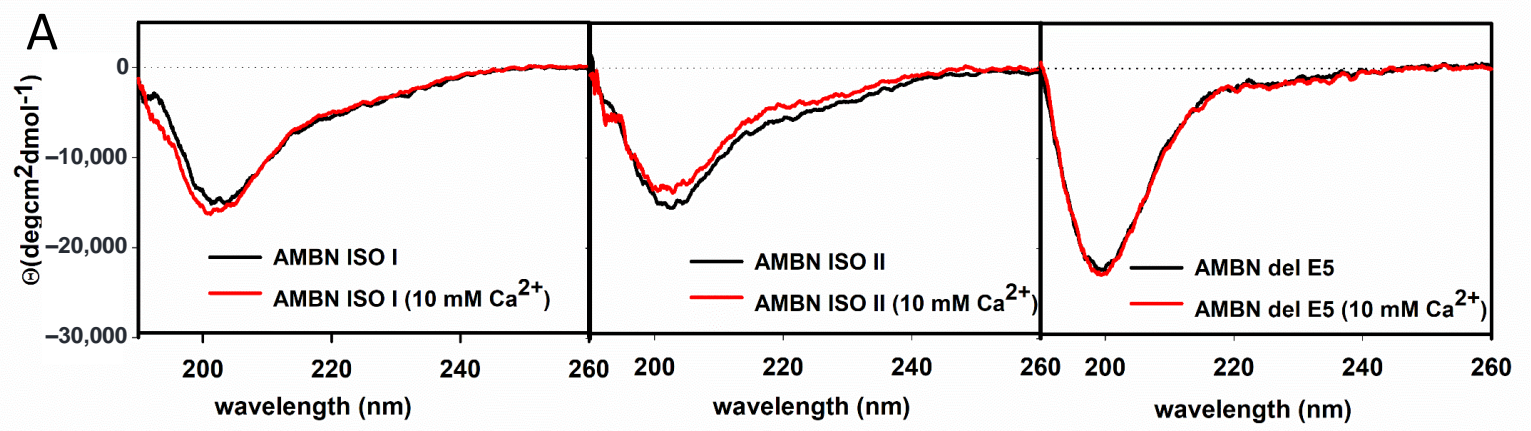

B

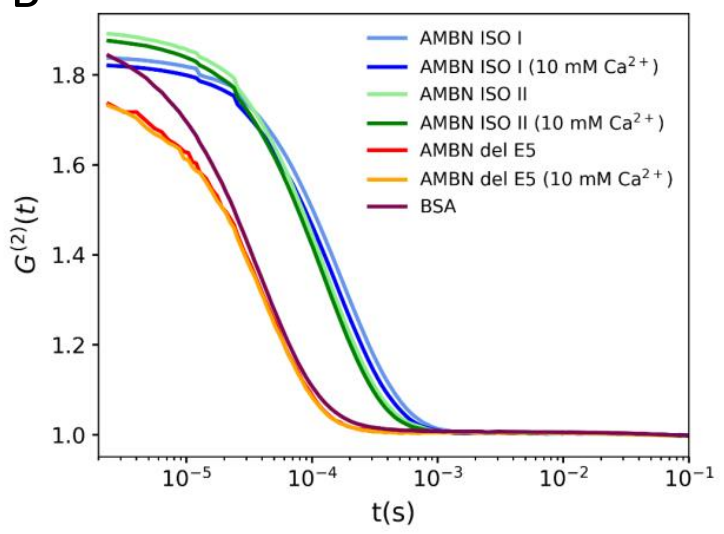

C

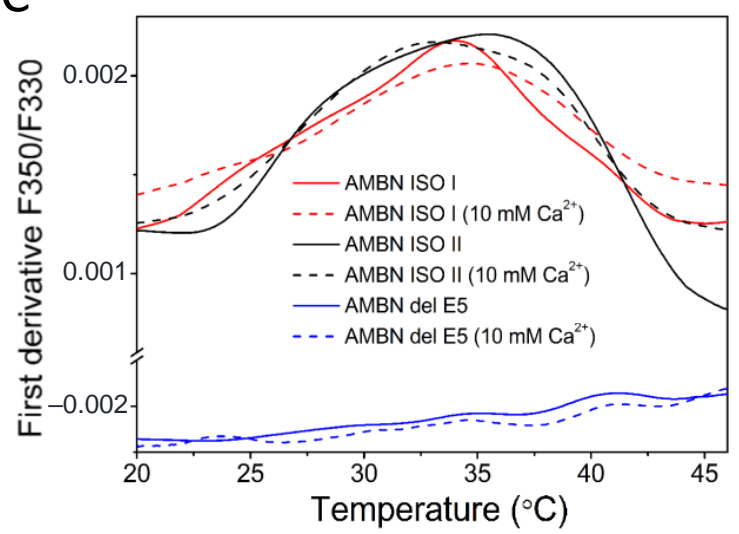

Figure 1. (A) Circular dichroism (CD) spectra of ameloblastin full-length isoform I (AMBN ISO I), ameloblastin full-length isoform II (AMBN ISO II) and AMBN with deleted exon 5 (AMBN del E5). Sample before (black) and after (red) addition of $10 \mathrm{mM} \mathrm{CaCl}_{2}$. (B) Analysis of autocorrelation functions (ACF) from dynamic light scattering (DLS) spectra of AMBN ISO I, AMBN ISO II, AMBN del E5, and bovine serum albumin (BSA) as a standard for globular protein. ACF of proteins in the absence or presence of $10 \mathrm{mM} \mathrm{CaCl}_{2}$. (C) First derivative of thermal unfolding curves of AMBN ISO I, AMBN ISO II, and AMBN del E5 in the presence or absence of $10 \mathrm{mM} \mathrm{CaCl}_{2}$.

\subsection{AMBN ISO I and AMBN ISO II form Organized Oligomers}

The measured autocorrelation functions $\mathrm{G}^{(2)}$ in Figure 1B for all studied molecules were obtained from a dynamic light scattering (DLS) experiment. The results show that the hydrodynamic radius of AMBN ISO I and AMBN ISO II in the $\mathrm{Ca}^{2+}$ buffer-free conditions is much larger than for AMBN del E5 construct and BSA used as a standard. This finding is fully consistent with observations by Wald et al. [2] who proved the importance of exon 5 for the oligomerization of AMBN ISO I. The analysis of autocorrelation functions (ACF) (Figure 1B) confirms the comparable behavior of both isoforms where AMBN ISO I is larger than AMBN ISO II. Unlike AMBN ISO I and AMBN ISO II, AMBN del E5 provided ACF corresponding to ACF of BSA standard used as a positive control to verify an AMBN del E5 monomeric character. The addition of $\mathrm{Ca}^{2+}$ into the solution caused only a small change of $\mathrm{Rh}$ of the both AMBN isoforms, keeping the size differences between AMBN ISO I and AMBN ISO II. All presented ACFs from DLS experiments were analyzed by second order cumulant fit and quantified by the corresponding z-averaged hydrodynamic radius [37] and polydispersity index (PDI) presented in Table 1. 
Table 1. Calculated hydrodynamic radii (Rh) [37] and polydispersity index (PDI) for AMBN ISO I, AMBN ISO II, AMBN del E5 variant of AMBN, and BSA in the absence or presence of $\mathrm{Ca}^{2+}$ ions. Numbers in parentheses represent the standard errors of the mean.

\begin{tabular}{ccccc}
\hline \multirow{2}{*}{ Protein } & \multicolumn{2}{c}{$\mathbf{~} \mathbf{M} \mathbf{C a C l}_{\mathbf{2}}$} & \multicolumn{2}{c}{$\mathbf{1 0} \mathbf{~} \mathbf{M ~ C a C l}_{\mathbf{2}}$} \\
\cline { 2 - 5 } & $\mathbf{R h} \mathbf{( n m})$ & $\mathbf{P D I}$ & $\mathbf{R h} \mathbf{( n m )}$ & $\mathbf{P D I}$ \\
\hline \multirow{2}{*}{ AMBN ISO I } & 24.0 & 0.13 & 21.6 & 0.09 \\
& $(0.2)$ & $(0.02)$ & $(0.2)$ & $(0.08)$ \\
\hline \multirow{2}{*}{ AMBN ISO II } & $17.7)$ & 0.12 & 16.9 & 0.09 \\
& $(0.1)$ & $(0.01)$ & $(0.1)$ & $(0.01)$ \\
\hline \multirow{2}{*}{ AMBN del E5 } & 5.7 & 0.06 & 5.7 & 0.06 \\
& $(0.05)$ & $(0.01)$ & $(0.05)$ & $(0.01)$ \\
\hline \multirow{2}{*}{ BSA } & 5.03 & 0.30 & \multirow{2}{*}{ NA } & NA \\
\hline
\end{tabular}

\subsection{AMBN Oligomers Partially Disintegrate by Increasing Temperature}

AMBN ISO I and AMBN ISO II are able to form stable oligomers at room temperature. The interaction interface between AMBN monomers in the oligomer is maintained by exon 5 via non-covalent interactions of composing amino acids. Therefore, the question of the stability of these oligomers at temperature or aggregation properties can be answered by CD spectroscopy and DSF.

As follows from the $\mathrm{CD}$ spectra (Figure S1), there is a qualitative difference between the $\mathrm{CD}$ spectrum measured at $20^{\circ} \mathrm{C}$ and $50^{\circ} \mathrm{C}$ for both AMBN isoforms. Apparently, the higher content of $\beta$-elements indicating the tendency of aggregation appears at $50{ }^{\circ} \mathrm{C}$ and continuously rises up to $90{ }^{\circ} \mathrm{C}$. Interestingly, all AMBN variants, including AMBN del E5, are to some extent fully reversible with temperature changes in the absence and presence of $\mathrm{Ca}^{2+}$.

Differential scanning fluorimetry (DSF) was used to illustrate changes in AMBN at the temperature range of about $20^{\circ} \mathrm{C}$ and $50{ }^{\circ} \mathrm{C}$. DSF data measured for AMBN ISO I, ISO II, and del E5 in the presence $\left(10 \mathrm{mM} \mathrm{CaCl}_{2}\right)$ and absence of $\mathrm{Ca}^{2+}$ were presented as the first derivative of the fluorescence emission ratio at $350 \mathrm{~nm}$ and $330 \mathrm{~nm}$ (F350/F330) (Figure 1C). It can be interpreted as disintegration peaks of the oligomeric forms of AMBN ISO I and AMBN ISO II with maxima around $35^{\circ} \mathrm{C}$. The disintegration occurs in both isoforms-AMBN ISO I and AMBN ISO II, and the presence of $\mathrm{Ca}^{2+}$ at $10 \mathrm{mM}$ concentration does not significantly influences this behavior. In contrast, the spectrum of AMBN del E5 does not show a sign of any transition; its first derivative represents a noisy line, and $T_{m}$ is not defined. This is in good agreement with the measured CD spectra of the AMBN del E5 showing an elevation of $\beta$-elements accompanying the aggregation. The data suggest that the AMBN ISO I and AMBN ISO II presented in oligomeric form first lose their oligomeric character with increasing temperature, and then, these non-oligomeric molecules begin to aggregate again, which most likely indicate a thermal non-specific aggregation.

The transmission electron microscopy (TEM) micrographs in Figure 2 confirmed that both AMBN ISO I and AMBN ISO II form oligomers, which are heterogeneous in size. The observation is supported by results from analytical ultracentrifugation (AUC) studies (see Results in Section 2.4, Figure 3A) and corresponds to the results published by Wald et al. [2].

Sedimentation velocity analysis performed by the analytical ultracentrifugation (AUC) technique confirmed that the presence of exon 5 in AMBN ISO I and AMBN ISO II is a necessary element for the substantial oligomerization of both isoforms. While a broad range of oligomeric states can be observed for full-length AMBN isoforms (Figure 3A), a monodisperse distribution of the sedimentation coefficient (S) was observed for AMBN del E5. The molecular weight of AMBN del E5 predicted from this measurement was $42 \mathrm{kDa}$, corresponding well to the expected $41 \mathrm{kDa}$ calculated from the protein amino acid sequence (Figure $3 \mathrm{~B}$ ). The fitted value of the frictional coefficients ratio $\mathrm{f} / \mathrm{f}_{0}$, describing asymmetry of the sedimenting particle [38], was for AMBN del E5 determined as 2.2, clearly suggesting 
its intrinsically disordered character. Similar values were fitted for the monomeric species present in the samples of both AMBN isoforms (Table 2). Their oligomeric forms span a range of values from 10 to $40 \mathrm{~S}$ for AMBN ISO I (on average 26.1 or $28.5 \mathrm{~S}$ in absence or presence of $\mathrm{Ca}^{2+}$, respectively) and from 10 to $30 \mathrm{~S}$ for AMBN ISO II (on average 19.2 or $20.9 \mathrm{~S}$ in absence or presence of $\mathrm{Ca}^{2+}$, respectively). Thus, the average values correspond to an approximate molecular weight of $1.30 \mathrm{MDa}$ or $1.54 \mathrm{MDa}$ for AMBN ISO I (with an average oligomer size of 28 or 33 monomers) in the absence or presence of $\mathrm{Ca}^{2+}$, respectively, and $855 \mathrm{kDa}$ or $900 \mathrm{kDa}$ for AMBN ISO II (with an average oligomer size of 19 and 20 monomers) in the absence or presence of $\mathrm{Ca}^{2+}$, respectively. The $\mathrm{f} / \mathrm{f}_{0}$ ratio of 1.6 to 1.7 fitted for the oligomeric species suggests that the oligomeric states might be slightly more compact due to the mutual interaction of the AMBN protein in both isoforms.

The AUC profile for AMBN ISO I and AMBN ISO II changes in the presence of $\mathrm{Ca}^{2+}$ as demonstrated by values for hydrodynamic properties of both monomeric (AMBN del E5) and oligomeric forms of AMBN. While for the AMBN del E5, only a small conformational change upon the addition of the $\mathrm{Ca}^{2+}$ was observed with its sedimentation coefficient shifting from 1.98 to $2.03 \mathrm{~S}$, and the fitted $\mathrm{f} / \mathrm{f}_{0}$ ratio decreasing from 2.2 to 2.1, a considerably bigger change was observed for both AMBN ISO I and AMBN ISO II oligomers. The oligomeric species in the presence of $\mathrm{Ca}^{2+}$ exhibited a higher level of compactness as evidenced by a small but consistent decrease of the fitted $\mathrm{f} / \mathrm{f}_{0}$ ratios (for AMBN ISO I decrease from 1.70 to 1.64 and for AMBN ISO II decrease from 1.72 to 1.63) as well as their Stokes hydrodynamic radii (Table 2), thereby sedimenting faster with higher values of the observed sedimentation coefficient (Figure 3A).
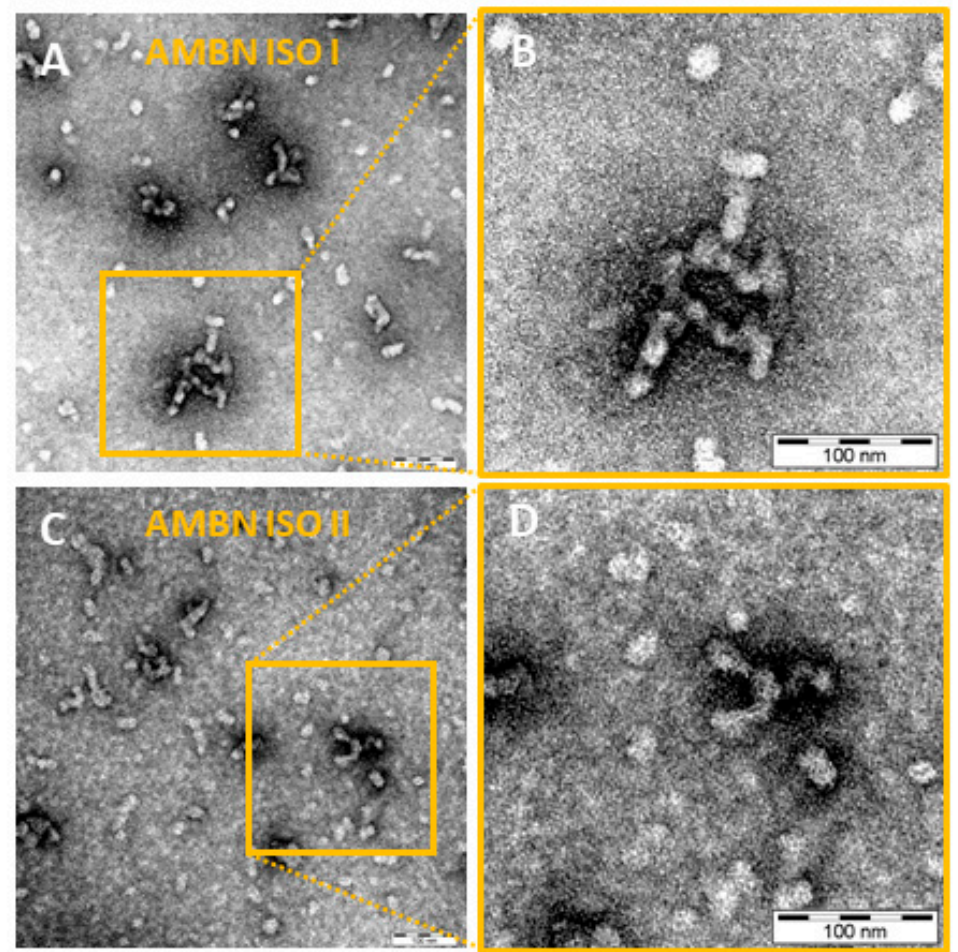

Figure 2. (A) Transmission electron micrographs of AMBN ISO I. Samples were examined at a magnification of 200,000x; scale bar $=100 \mathrm{~nm}$. (B) Magnified detail of the AMBN ISO I presented in panel A. (C) Transmission electron micrographs of AMBN ISO II. Samples were examined at a magnification of 200,000×; scale bar $=100 \mathrm{~nm}$. (D) Magnified detail of the AMBN ISO II presented in panel C. 

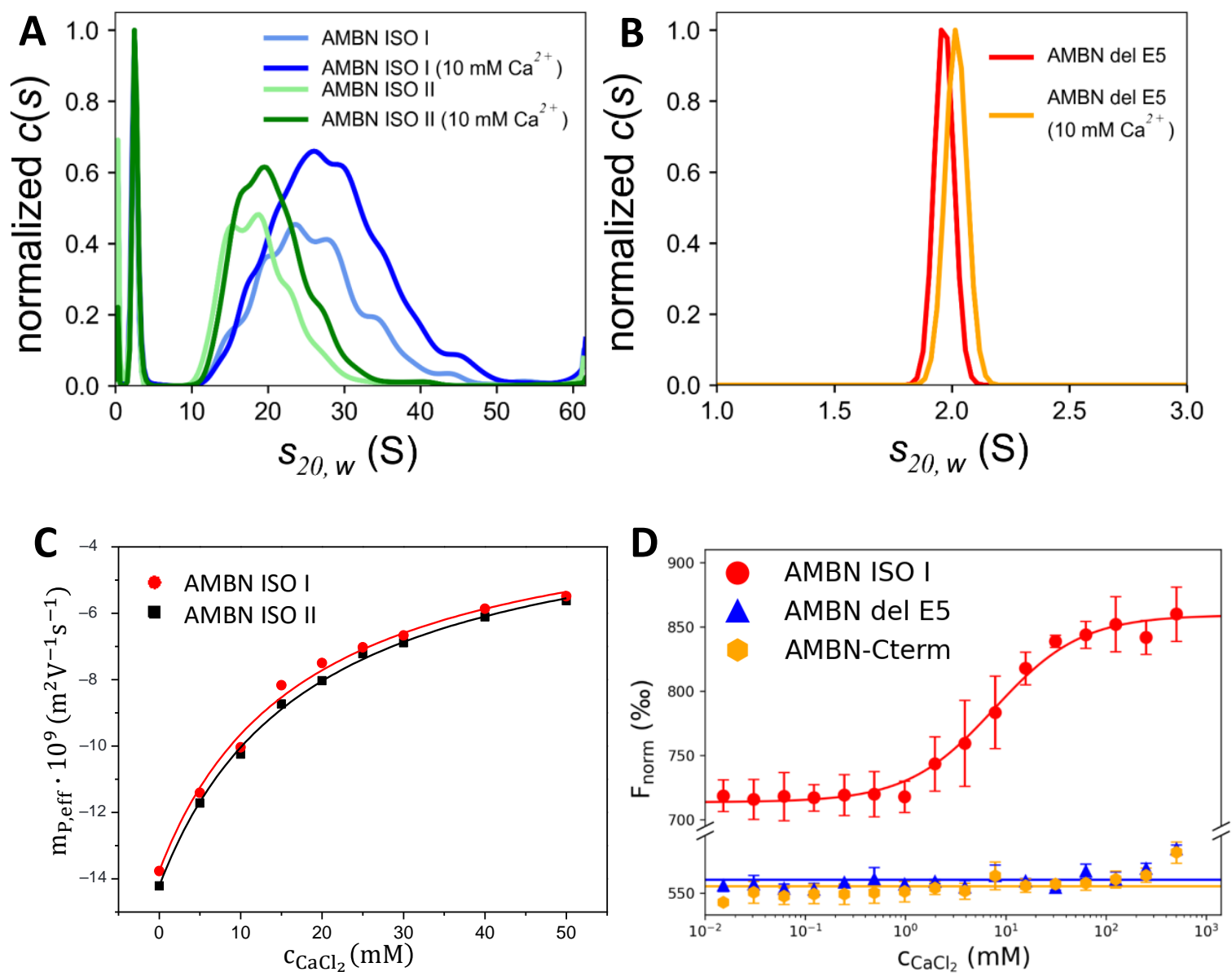

Figure 3. Sedimentation velocity analysis of (A) AMBN ISO I and AMBN ISO II; (B) AMBN del E5; in the absence or presence of $10 \mathrm{mM} \mathrm{CaCl}_{2}$. (C) Dependence of the effective electrophoretic mobility, $m_{P, e f f}$, of AMBN ISO I and AMBN ISO II proteins on the concentration of $\mathrm{CaCl}_{2}\left(\mathrm{c}_{\mathrm{CaCl}_{2}}\right)$, in the background electrolyte (BGE) composed of $30 \mathrm{mM}$ Tris, $25 \mathrm{mM}$ acetic acid, $\mathrm{pH}=7.4$. (D) Microscale thermophoresis analysis of the interaction of the AMBN ISO I, AMBN del E5, and AMBN-Cterm with $\mathrm{CaCl}_{2}$. Titration of $\mathrm{CaCl}_{2}$ against a constant concentration of AMBN ISO I revealed a standard binding curve, while the titration of AMBN del E5 and AMBN C-term shows no binding.2.4. AMBN Oligomers of Both Isoforms Have a Heterogenous Character.

Table 2. Stokes hydrodynamic radii $\left(R_{S}\right)$ estimated from analytical ultracentrifugation (AUC) sedimentation velocity data for AMBN ISO I, ISO II, and del E5 variants and BSA in the absence or presence of $\mathrm{Ca}^{2+}$ ions.

\begin{tabular}{|c|c|c|c|c|c|c|}
\hline \multirow{2}{*}{ Protein } & \multicolumn{3}{|c|}{$0 \mathrm{mM} \mathrm{CaCl} 2$} & \multicolumn{3}{|c|}{$10 \mathrm{mM} \mathrm{CaCl} 2$} \\
\hline & $\mathrm{R}_{\mathrm{S}}(\mathrm{nm})$ & $\mathrm{s}_{20, \mathrm{w}}(\mathrm{S})$ & $\mathbf{f} / \mathbf{f}_{0}$ & $\mathrm{R}_{\mathrm{S}}(\mathrm{nm})$ & $\mathrm{s}_{20, \mathrm{w}}(\mathrm{S})$ & $\mathbf{f} / \mathbf{f}_{0}$ \\
\hline AMBN ISO I monomer & 4.44 & 2.53 & 2.09 & 4.30 & 2.61 & 2.02 \\
\hline AMBN ISO I oligomers & 15.5 & 26.1 & 1.70 & 15.4 & 28.5 & 1.64 \\
\hline AMBN ISO II monomer & 4.28 & 2.53 & 2.05 & 4.10 & 2.65 & 2.18 \\
\hline AMBN ISO II oligomers & 13.5 & 19.2 & 1.72 & 13.0 & 20.9 & 1.63 \\
\hline AMBN del E5 & 4.98 & 1.98 & 2.20 & 4.85 & 2.03 & 2.10 \\
\hline BSA & 3.38 & 4.60 & 1.27 & NA & NA & NA \\
\hline
\end{tabular}

\subsection{AMBN Binds $\mathrm{Ca}^{2+}$ Only in Its Oligomeric Form}

The records of capillary electrophoresis (CE) analyses of AMBN ISO I and AMBN ISO II proteins are presented in Figure S3. CE analyses in the buffered background electrolyte (BGE) containing $\mathrm{Ca}^{2+}$ showed that the migration times of proteins were increasing more significantly than the migration 
times of the electroosmotic flow marker dimethylsulphoxide (DMSO) with the increasing concentration of $\mathrm{Ca}^{2+}$ (Figure S3). This indicates an interaction between the proteins and $\mathrm{Ca}^{2+}$. The dependences of the effective electrophoretic mobilities of AMBN proteins on the concentration of $\mathrm{Ca}^{2+}$ in the BGE are shown in Figure $3 \mathrm{C}$. The apparent binding constants $\mathrm{K}_{\mathrm{b}}$ and their reciprocal values (apparent dissociation constants, $\mathrm{K}_{\mathrm{D}}$ ) and ionic mobilities of the protein- $\mathrm{Ca}^{2+}$ complexes obtained by regression analysis of CE data are presented in Table 3. The CE records and data in Table 3 show that AMBN ISO I and AMBN ISO II proteins interact with $\mathrm{Ca}^{2+}$ with the apparent dissociation constant $\left(\mathrm{K}_{\mathrm{D}}\right)$ of the protein- $\mathrm{Ca}^{2+}(1: 1)$ complexes similarly for both AMBN isoforms: AMBN ISO I $\left(\mathrm{K}_{\mathrm{D}}=17 \mathrm{mM}\right)$ and AMBN ISO II $\left(K_{D}=18 \mathrm{mM}\right)$. These relatively high values of $K_{D}$ (low values of $\mathrm{Kb}, 54.4-56.8 \mathrm{~L} / \mathrm{mol}$, see Table 3) show that the interactions of AMBN ISO I and AMBN ISO II protein with $\mathrm{Ca}^{2+}$ cations are relatively weak. They are much weaker than the $\mathrm{Ca}^{2+}$ complexes with e.g., C-reactive protein, $\mathrm{K}_{\mathrm{D}}=59 \mu \mathrm{M}$ [39]; on the other hand, there is a spectrum of secretory calcium-binding phosphoproteins (SCPPs) in wide range of affinities from $\mathrm{nM}$ to $\mathrm{mM} \mathrm{[40].}$

Table 3. The calculated apparent binding constants, $\mathrm{K}_{\mathrm{b}}$, dissociation constant, $\mathrm{K}_{\mathrm{D}}$, and the ionic mobilities, $m_{\mathrm{PM}}$, of the complexes of AMBN ISO I and AMBN ISO II proteins with $\mathrm{Ca}^{2+}$, and electrophoretic mobilities of these proteins in the background electrolyte free of $\mathrm{Ca}^{2+}, m_{\mathrm{p}, \mathrm{eff}, 0} ; \mathrm{R}^{2}$, coefficient of determination.

\begin{tabular}{|c|c|c|c|c|c|}
\hline Protein & $\begin{array}{c}\mathrm{K}_{\mathrm{b}} \pm \mathrm{SD}^{\mathrm{a}} \\
(\mathrm{L} / \mathrm{mol})\end{array}$ & $\begin{array}{c}m_{\mathrm{p}, \mathrm{eff}, 0} \pm \mathrm{SD}^{\mathrm{a}} \\
\left(10^{-9} \mathrm{~m}^{2} \mathrm{~V}^{-1} \mathrm{~s}^{-1}\right)\end{array}$ & $\begin{array}{c}m_{\mathrm{PM}} \pm \mathrm{SD}^{\mathrm{a}} \\
\left(10^{-9} \mathrm{~m}^{2} \mathrm{~V}^{-1} \mathrm{~s}^{-1}\right)\end{array}$ & $\mathbf{R}^{2}$ & $\underset{(\mathrm{mol} / \mathrm{L})}{\mathrm{K}_{\mathrm{D}} \pm \mathrm{SD}^{\mathrm{a}}}$ \\
\hline AMBN ISO I & $56.8 \pm 6.3$ & $-13.8 \pm 0.2$ & $-2.39 \pm 0.51$ & 0.993 & $0.017 \pm 0.002$ \\
\hline AMBN ISO II & $54.4 \pm 3.0$ & $-14.2 \pm 0.2$ & $-2.36 \pm 0.27$ & 0.998 & $0.018 \pm 0.001$ \\
\hline
\end{tabular}

To confirm the above obtained values by CE, we used the microscale thermophoresis (MST) method to determine binding properties of at least one of the isoforms, AMBN ISO I, which represents the oligomeric form of AMBN. For comparison, we took the AMBN del E5 construct, representing the monomeric form of AMBN as the control. To complete the characterization of $\mathrm{Ca}^{2+}$-binding properties of AMBN, we analyzed AMBN-Cterm (exon10-exon13), which is highly negatively charged and does not form oligomers. An interaction between AMBN ISO I and $\mathrm{Ca}^{2+}$ was clearly confirmed, whereas for AMBN del E5- $\mathrm{Ca}^{2+}$ and AMBN-Cterm-Ca ${ }^{2+}$, no interaction was detected (Figure 3D). Therefore, we conclude that the oligomeric form of $\mathrm{AMBN}$ proteins is the major condition for $\mathrm{Ca}^{2+}$ binding. Although the dissociation constant $\left(\mathrm{K}_{\mathrm{D}}\right)$ for AMBN ISO I was determined in the low $\mathrm{mM}$ range $(7.7 \mathrm{mM})$, it should be noted that the value is apparently the average of $\mathrm{K}_{\mathrm{Ds}}$ due to the oligomerization heterogeneity of the AMBN ISO I. It is known that affinities for cellular proteins binding $\mathrm{Ca}^{2+}$ span the range from $\mathrm{nM}$ to $\mathrm{mM}$ [40-43], which is in agreement with our determined $\mathrm{K}_{\mathrm{D}}$.

\section{Discussion}

The main determinant of the properties of AMBN ISO I and AMBN ISO II is their IDP character [1]. However, many AMBN-associated functions can be deduced from its behavior under physiological conditions in which the presence of $\mathrm{Ca}^{2+}$ [44] is frequent. The fact that AMBN is present in two isoforms-AMBN ISO I and AMBN ISO II-suggests that they could have different roles not only during the enamel formation but also during specific cellular functions. Different AMBN mRNA splicing resulting in the presence of AMBN ISO I and ISO II may lead to their various proteolytic profiles and interaction properties, which may lead to products with different functions [45,46]. We compared a large spectrum of AMBN ISO I and ISO II properties, which both have been shown to exist under physiological conditions in oligomeric states. This is in contrast to AMBN del E5 present only as a monomer. Still, AMBN ISO I and II as well as AMBN del E5 are preserving their IDP character in all performed $\mathrm{CD}$ experiments (without and in the presence of $\mathrm{Ca}^{2+}$ cations), as was confirmed by $\mathrm{CD}$ 
spectroscopy (Figure 1A). It is also in a good agreement with an analysis of computational disorder prediction by D2P2 (Figure S2).

The oligomeric and heterogeneous characters of AMBN ISO I and ISO II were further confirmed by DLS in the $\mathrm{Ca}^{2+}$ buffer-free conditions as well as in the presence of $\mathrm{Ca}^{2+}$. In addition, there appear to be small differences in the size and distribution of AMBN oligomers of both isoforms (AMBN ISO I creates larger oligomers than AMBN ISO II), as confirmed by TEM. It should be mentioned that we have to take into account the detection limit of the TEM resolution (Figure 2). This is in contrast to the behavior of AMBN del E5 confirmed by DLS and AUC methods, which exhibit monomeric protein properties (Figure 1B). AUC was employed to characterize the oligomeric state of AMBN and its variants. As clearly demonstrated by the presented results, the AMBN del E5 retained its monomeric character even in the presence of $\mathrm{Ca}^{2+}$, which is in sharp contrast to the observable effect of $\mathrm{Ca}^{2+}$ on AMBN ISO I and AMBN ISO II. We again assigned this difference to the oligomeric nature of both isoforms and confirmed that exon 5 is the most important prerequisite for oligomerization. AUC also provided results indicating the effect of $\mathrm{Ca}^{2+}$ demonstrated by the increased compactness of AMBN ISO I and ISO II. However, it is difficult to discern whether this behavior was due to a conformational change of the same oligomeric species or due to a shift in distribution toward higher AMBN oligomers caused by the $\mathrm{Ca}^{2+}$.

The temperature response of AMBN proteins was studied by CD spectrometry and DSF. DSF is commonly used to determine the melting temperature of denaturated protein [47]. In our case, we addressed a question of disintegration of the oligomeric state of AMBN. As follows from the temperature-dependent $C D$ spectra, an interesting temperature interval was identified between 20 and $50{ }^{\circ} \mathrm{C}$. The DSF results show similar behavior of both AMBN isoforms under two different conditions $\left(\mathrm{Ca}^{2+}\right.$ free and $10 \mathrm{mM} \mathrm{Ca}^{2+}$ solutions) and suggest that there is a transition state attributable to the disintegration of AMBN oligomeric states into smaller oligomers and/or monomers. Both the CD as well as DSF spectra show the formation of higher AMBN aggregates upon increasing temperature, which was presumably formed non-specifically.

The final step of the study was to investigate the binding affinity of $\mathrm{Ca}^{2+}$ to AMBN isoforms. We performed CE and MST to determine the dissociation constants of $\mathrm{Ca}^{2+}$ complexes. From the CE results, we can conclude that both AMBN isoforms act as low affinity $\mathrm{Ca}^{2+}$-binding proteins with the similar $\mathrm{K}_{\mathrm{D}}$. The MST experiment confirmed the binding of $\mathrm{Ca}^{2+}$ to AMBN ISO I, whereas no binding of $\mathrm{Ca}^{2+}$ was observed for AMBN del E5 and AMBN-Cterm, representing the monomeric states. It seems to be clear to conclude that the oligomeric state of AMBN is crucial for $\mathrm{Ca}^{2+}$ binding. Interestingly, the MST experiment determined a similar binding constant as determined by CE (for AMBN ISO I). To establish a schema of the potential mechanism of $\mathrm{Ca}^{2+}$ binding to AMBN oligomers, we propose a model of the oligomeric arrangement of AMBN in the absence and presence of $\mathrm{Ca}^{2+}$ (Figure 4). AMBN in solution without $\mathrm{Ca}^{2+}$ creates stable oligomers with flexible and dynamic AMBN-Cterm parts due to their disordered character. In the presence of $\mathrm{Ca}^{2+}$, the oligomeric form of AMBN becomes less dynamic at AMBN-Cterm due to stabilization introduced by interchain interactions of AMBN C-termini facilitated by $\mathrm{Ca}^{2+}$. This is in qualitative agreement with the AUC results, which show that both AMBN isoforms are slightly more compact in the presence of $\mathrm{Ca}^{2+}$ (Figure 2A).

The reason why we studied both isoforms and their spatial organization is that these extra 15 amino acids presented in Ambn ISO I lie just next to the exon 5 sequence, which is known to be the only element responsible for oligomerization. To use an analogy, the deletion of exon 5 ( 37 amino acids) completely removes the ability of the Ambn to create oligomers. The sequence of these 15 amino acids just next to the exon 5 terminus seems to be a good candidate for modulation of the oligomerization but to a lesser extent than exon 5 itself. Additionally, the sequence composition of these 15 amino acids is rich for tyrosines known for their role in protein-protein interactions. Whether the extension of exon 5 completely missing in ISO II could influence the oligomerization, size, or their tendency to aggregate was not clear, and we had to explore the possible consequences of the missing part of the sequence experimentally. We conclude that this is an extra element of modulation of oligomerization level. 


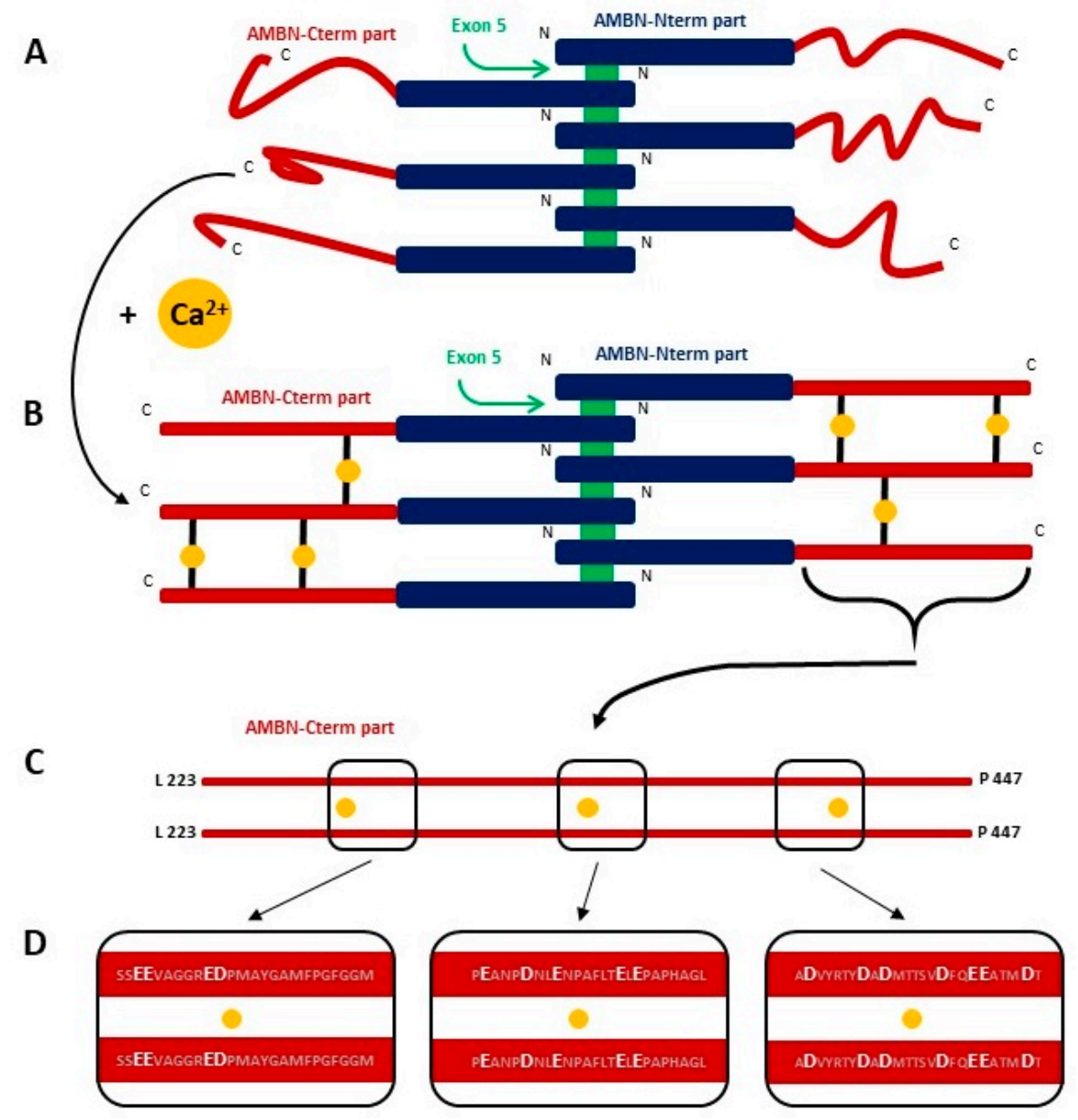

Figure 4. The schematic view of possible AMBN oligomerization state. AMBN monomers forming oligomers (e.g., hexamer). The blue rectangle illustrates AMBN-Nterm, while the green rectangle shows oligomerization inducing exon 5. Red lines show the possible arrangements of AMBN-Cterm in the absence of $\mathrm{Ca}^{2+}(\mathbf{A})$ and in the presence of $\mathrm{Ca}^{2+}(\mathbf{B})$ with yellow circles representing $\mathrm{Ca}^{2+}$. Black lines represent possible $\mathrm{Ca}^{2+}$ binding to AMBN-Cterm. (C) Schematic detail of possible $\mathrm{Ca}^{2+}$-binding sites of two C-termini of AMBN. Black rectangles represent sequences with a high abundance of negatively charged amino acids. (D) Detail view of potential $\mathrm{Ca}^{2+}$-binding sites at AMBN C-termini is shown in panel C. Amino acid sequences of AMBN-Cterm are in black rectangles. Negatively charged amino acids as a high preferable binding sites are bold white.

\section{Materials and Methods}

\subsection{Design of AMBN Plasmid Constructs}

The expression vectors encoding AMBN ISO I, AMBN del E5, and AMBN-Cterm were kindly provided by the Institute of Microbiology of the CAS (Prague, Czech Republic) [2]; the vector encoding AMBN ISO II was obtained from the University of Chemistry and Technology (Prague, Czech Republic). The cDNA of AMBN were subcloned into the pET28b vector in fusion with 6xHis and the thioredoxin tags (Trx) removable with Tobacco Etch Virus (TEV) protease (for details, see [2]).

\subsection{Protein Expression and Purification}

AMBN ISO I (UniProtKB-Q9NP70-1), AMBN ISO II (UniProtKB-Q9NP70-2), AMBN del E5, and AMBN-Cterm were produced as recombinant proteins in Escherichia coli BL21(DE3) cells. Cultures were grown in Luria-Bertani (LB) broth with kanamycin $(30 \mu \mathrm{g} / \mathrm{mL})$ at $37^{\circ} \mathrm{C}$. The expression was induced by $0.5 \mathrm{mM}$ isopropyl- $\beta$-D-thiogalactopyranoside and cultivation continued for $20 \mathrm{~h}$ at 
lower temperatures $\left(14{ }^{\circ} \mathrm{C}\right.$ for AMBN ISO I, $16{ }^{\circ} \mathrm{C}$ for AMBN ISO II, $30^{\circ} \mathrm{C}$ for AMBN del E5, $15{ }^{\circ} \mathrm{C}$ for AMBN-Cterm). Cells were harvested by centrifugation, resuspended in a phosphate buffer: $50 \mathrm{mM}$ $\mathrm{Na}_{2} \mathrm{HPO}_{4}(\mathrm{pH}=8.0), 50 \mathrm{mM} \mathrm{NaCl}, 0.1 \% 2$-mercaptoethanol, and stored at $-80^{\circ} \mathrm{C}$. Following thawing, the cells were sonicated at $4{ }^{\circ} \mathrm{C}$, centrifuged for $1 \mathrm{~h}$ at $21,000 \times g$; then, $8 \mathrm{M}$ urea was added into the lysate. The lysate was purified by metal affinity chromatography using Chelating Sepharose Fast Flow resin (GE Healthcare Bio-Sciences $\mathrm{AB}$, Uppsala, Sweden) charged with $\mathrm{Ni}^{2+}$ ions in an equilibration buffer ( $8 \mathrm{M}$ urea, $50 \mathrm{mM}$ Tris- $\mathrm{HCl}(\mathrm{pH}=7.4), 600 \mathrm{mM} \mathrm{NaCl}$, and $20 \mathrm{mM}$ imidazole). The bound proteins were eluted from the column by elution buffer containing $600 \mathrm{mM}$ imidazole, and following renaturation, His-tagged TEV protease was added to the sample to remove His and Trx tags from AMBN proteins. Then, the whole reaction mixture was loaded again on the top of the HisTrap HP column (GE Healthcare Bio-Sciences AB, Uppsala, Sweden), and eluted AMBN ISO I and AMBN ISO II proteins were dialyzed overnight at $4{ }^{\circ} \mathrm{C}$ against a loading buffer containing $10 \mathrm{mM}$ Tris- $\mathrm{HCl}$ $(\mathrm{pH}=7.4), 100 \mathrm{mM} \mathrm{NaCl}$. Then, $10 \mathrm{mM}$ ethyleneglycol-bis(beta-aminoethylether)-N, $\mathrm{N}^{\prime}$-tetraacetic acid (EGTA) was added to the mixture, and following $4 \mathrm{~h}$ incubation, the sample was dialyzed overnight at $4{ }^{\circ} \mathrm{C}$ against a loading buffer. AMBN del E5 and AMBN-Cterm were incubated with $10 \mathrm{mM}$ EGTA for $4 \mathrm{~h}$ and then loaded on a Superdex 200 Increase 10/300 GL column (GE Healthcare Bio-Sciences $\mathrm{AB}$, Uppsala, Sweden) equilibrated with $10 \mathrm{mM}$ Tris- $\mathrm{HCl}(\mathrm{pH}=7.4), 100 \mathrm{mM} \mathrm{NaCl}$. The mass of all recombinant proteins was determined as follows: AMBN ISO I $=46.71 \mathrm{kDa}$; AMBN ISO II $=45.00 \mathrm{kDa}$; AMBN del E5 $=41.09 \mathrm{kDa}$; AMBN-Cterm $=25.36 \mathrm{kDa}$. The purity of the final samples was analyzed by SDS-PAGE (Figure S4), and AMBN protein sequences were verified by MS.

\subsection{Circular Dichroism Spectroscopy}

CD spectra were collected on a Jasco-1500 spectropolarimeter equipped with a Peltier thermostated holder PTC-517 (JASCO Inc., Easton, MD, USA) at room temperature (RT) and/or additionally at the temperature range $5-95^{\circ} \mathrm{C}$ with an increment of $5{ }^{\circ} \mathrm{C}$ using the following experimental setup: (i) for RT from 190 to $300 \mathrm{~nm}, 0.1 \mathrm{~mm}$ cylindrical quartz cell, standard instrument sensitivity, $1 \mathrm{~nm}$ bandwidth, a scanning speed of $5 \mathrm{~nm} / \mathrm{min}$, a response time of $16 \mathrm{~s}$, and two spectra accumulations; (ii) temperature dependence from 195 to $280 \mathrm{~nm}$, a $0.2 \mathrm{~mm}$ rectangular quartz cell, standard instrument sensitivity, a $1 \mathrm{~nm}$ bandwidth, a scanning speed of $10 \mathrm{~nm} / \mathrm{min}$, a response time of $8 \mathrm{~s}$, and one accumulation. The temperature reversibility was checked by measurement of the chilled solution back to $5^{\circ} \mathrm{C}$. After baseline subtraction, the final data were expressed as molar ellipticities $\theta\left(\mathrm{deg} \cdot \mathrm{cm}^{2} \cdot \mathrm{dmol}^{-1}\right)$ per residue.

The AMBN samples have been prepared in the absence of $\mathrm{Ca}^{2+}$, and the same batch have been used for analyses in the presence of $10 \mathrm{mM} \mathrm{CaCl}_{2}$. Samples were measured in buffer $(10 \mathrm{mM}$ Tris- $\mathrm{HCl}$ $(\mathrm{pH}=7.4)$ with $100 \mathrm{mM} \mathrm{NaCl}$ ) and in concentration $23 \mu \mathrm{M}$.

\subsection{Dynamic Light Scattering}

DLS experiments were performed using an RiNA Laser Spectroscater 201 (RiNa, Berlin, Germany). All samples were measured at $18^{\circ} \mathrm{C}$, using an angle of $90^{\circ}$. Each sample was measured 60 times, and the acquisition time was 2 seconds. AMBN ISO I, AMBN ISO II, and AMBN del E5 purified in the absence of $\mathrm{Ca}^{2+}$ at a concentration $14 \mu \mathrm{M}$ were used for measurements, as well as BSA as a standard. All samples were analyzed in $10 \mathrm{mM}$ Tris- $\mathrm{HCl}(\mathrm{pH}=7.4)$ with a $100 \mathrm{mM} \mathrm{NaCl}$ buffer. Measurements of these samples were also performed in the presence of $10 \mathrm{mM} \mathrm{CaCl}_{2}$, which was added directly to these samples 30 minutes before the experiment. Protein solutions have been centrifuged before each measurement at $4{ }^{\circ} \mathrm{C}$. The measured raw $G^{(2)}$ autocorrelation functions (ACF) were recorded and thoroughly examined for artefacts. Measurements with a residual baseline or anomalous photocurrent count rate were discarded. Individual autocorrelograms were fitted by second-order cumulant analysis providing z-averaged size and polydispersity index (PDI). Hydrodynamic radii (Rh) [37] were estimated using the Stokes-Einstein relation. The reported values of Rh and PDI were 
calculated as the arithmetic average over 40-60 analyzed autocorrelation curves. Their uncertainty was estimated as the standard errors of the mean (SEM).

\subsection{Analytical Ultracentrifugation}

Sedimentation velocity measurements were performed on an analytical ultracentrifuge ProteomeLab XL-I (Beckman Coulter, Indianapolis, IN, USA) [48]. AMBN ISO I, AMBN ISO II, and AMBN del E5 samples at $23 \mu \mathrm{M}$ concentration purified in the absence of $\mathrm{Ca}^{2+}$ were analyzed in a $10 \mathrm{mM}$ Tris- $\mathrm{HCl}(\mathrm{pH}=7.4), 100 \mathrm{mM} \mathrm{NaCl}$ buffer. Alternatively, $\mathrm{CaCl}_{2}$ was added to $10 \mathrm{mM}$ final concentration prior to the analysis to these samples using the same batch of protein. Sedimentation velocity experiments were conducted at $20^{\circ} \mathrm{C}$ at 25,000 (AMBN ISO I and AMBN ISO II) or 48,000 (AMBN del E5) rpm using double sector cells and an An50-Ti rotor. In total, 250 absorbance scans were recorded at $280 \mathrm{~nm}$ in 4 min intervals. Buffer density, protein partial specific volumes, values of sedimentation coefficients corrected to standard conditions, and particle dimensions were estimated in Sednterp v1.10 [49]. Data were analyzed in Sedfit v16.36 [50] using a continuous sedimentation coefficient distribution $\mathrm{c}(\mathrm{s})$ with bimodal $\mathrm{f} / \mathrm{f}_{0}$ model yielding a separate $\mathrm{f} / \mathrm{f}_{0}$ values for monomeric and oligomeric AMBN species. Figures were prepared in GUSSI v1.4.6 [51].

\subsection{Differential Scanning Fluorimetry}

A Prometheus nanoDSF instrument (NanoTemper Technologies, Munich, Germany) was used to determine the temperature dependence of the intrinsic dual-UV fluorescence change in tryptophan and tyrosine residues. Capillaries were loaded with $10 \mu \mathrm{L}$ of protein sample at $14 \mu \mathrm{M}$ concentration and emission wavelengths $\lambda=330$ and $350 \mathrm{~nm}$ were measured. The experiment was performed at a heating rate of $1.5^{\circ} \mathrm{C} /$ minute, resulting in a data point density of 15 points $/{ }^{\circ} \mathrm{C}$. To determine the melting point temperature $T_{m}$, the ratio of the fluorescence intensities at both emission wavelengths (F350/F330) was used. Its first derivative displaying a peak at the point of maximal slope, which corresponds for globular proteins to the $\mathrm{T}_{\mathrm{m}}$, was plotted. AMBN proteins (AMBN ISO I, AMBN ISO II and AMBN del E5) were analyzed in a $10 \mathrm{mM}$ Tris- $\mathrm{HCl}(\mathrm{pH}=7.4), 100 \mathrm{mM} \mathrm{NaCl}$ buffer. $\mathrm{CaCl}_{2}$ was added to $10 \mathrm{mM}$ final concentration prior to the analysis of AMBN proteins.

\subsection{Transmission Electron Microscopy}

AMBN ISO I and AMBN ISO II proteins at a concentration of $1.3 \mu \mathrm{M}$ were visualized in $10 \mathrm{mM}$ Tris- $\mathrm{HCl}(\mathrm{pH}=7.4), 100 \mathrm{mM} \mathrm{NaCl}$ buffer by negative stain transmission electron microscopy. Parlodion-carbon-coated grids were floated on the top of a $5 \mathrm{uL}$ drop of the sample for $5 \mathrm{~min}$. Then, the grids were transferred on the top of drop $2 \%$ uranyl acetate, stained for $2 \times 15 \mathrm{~s}$, and dried. Photomicrographs were taken with a JEOL JEM-1011 electron microscope (Peabody, MA, USA) operated at $80 \mathrm{kV}$.

\subsection{Capillary Electrophoresis}

CE analyses were performed in P/ACE MDQ System (Beckman Coulter, Fullerton, CA, USA) using the software P/ACE System MDQ, the Karat version (Beckman), and the Clarity data station (DataApex, Prague, Czech Republic) for data acquisition and evaluation [52]. The CE analyzer was equipped with a UV-vis photodiode array spectrophotometric detector (190-600 nm) set at $200 \mathrm{~nm}$ wavelength. CE analyses were carried out in the internally untreated fused silica capillary, total/effective (to the UV-detector) length $405 / 302 \mathrm{~mm}$, inside/outside diameter 50/375 $\mu \mathrm{m}$, with outer polyimide coating (Polymicro Technologies, Phoenix, AR, USA). The buffered background electrolyte (BGE) was composed of $30 \mathrm{mM}$ Tris and $25 \mathrm{mM}$ acetic acid $(\mathrm{pH}=7.4)$. DMSO has been used as an electroneutral marker of electroosmotic flow. The new capillary was consecutively washed with $1 \mathrm{M} \mathrm{NaOH}$, water, and the BGE with a pressure of 1 bar for $10 \mathrm{~min}$ each, and conditioned in the BGE at a separation voltage of $20 \mathrm{kV}$ for $20 \mathrm{~min}$. Between analytical runs, the capillary was rinsed with the BGE with a pressure of 1 bar for $2 \mathrm{~min}$. The analyses were performed at a constant temperature of $25^{\circ} \mathrm{C}$ inside 
the capillary using the constant input power of $0.4 \mathrm{~W}$ and cooling the outer capillary wall by liquid coolant to the temperature $21.8^{\circ} \mathrm{C}$. Separation voltage was in the range of $10.6-24.0 \mathrm{kV}$, and electric current varied between 17.1 and $37.9 \mu \mathrm{A}$. AMBN ISO I and AMBN ISO II were analyzed in a $10 \mathrm{mM}$ Tris- $\mathrm{HCl}(\mathrm{pH}=7.4), 100 \mathrm{mM} \mathrm{NaCl}$ buffer. The concentration of AMBN proteins was $13 \mu \mathrm{M}$.

\subsection{Microscale Thermophoresis}

MST measurement and analysis of $\mathrm{Ca}^{2+}$-binding properties of AMBN ISO I, AMBN del E5, and AMBN-Cterm was performed as follows: a series of $\mathrm{CaCl}_{2}$ dilutions $(500-0.015 \mathrm{mM})$ were incubated with AMBN ISO I $(1.3 \mu \mathrm{M})$, AMBN del E5 $(3.4 \mu \mathrm{M})$, and AMBN-Cterm $(3.2 \mu \mathrm{M})$ in $10 \mathrm{mM}$ Tris- $\mathrm{HCl}(\mathrm{pH}=7.4), 100 \mathrm{mM} \mathrm{NaCl}$, and $0.05 \%$ Tween 20 for $30 \mathrm{~min}$ at $26^{\circ} \mathrm{C}$. The reactions were measured in Label-Free Premium capillaries on a Monolith NT. Label-Free instrument (NanoTemper Technologies, Munich, Germany) using $25 \%$ or $30 \%$ LED power and $40 \%$ MST IR laser power. All experiments were performed in triplicate. The plot was created using Matplotlib 3.2.1 [53]. The binding constants measured by MST were calculated using NTAnalysis software, v1.5.41 (Nanotemper Technology GmbH, Munich, Germany).

\section{Conclusions}

Human AMBN belongs to IDPs, which in fact significantly expands the portfolio of its functions with respect to the primary role of the protein involved in enamel formation. The presence of the two AMBN isoforms AMBN ISO I and AMBN ISO II has raised experimental questions as to whether biophysical properties are the main determinants of their different roles or whether there is another event to which the two isoforms respond differently. The results of this study only partially answered this question. Both isoforms exist only in the oligomeric form for which the exon 5 sequence is responsible. The isoforms bind $\mathrm{Ca}^{2+}$ with millimolar affinity, and it is only the oligomeric state that allows this binding. The deletion of exon 5 completely erases this ability, as demonstrated by MST experiments. The most important finding was that $\mathrm{Ca}^{2+}$ is able to bind to both isoforms, potentially suggesting that $\mathrm{AMBN}$ could act as a special $\mathrm{Ca}^{2+}$ buffer, especially in a $\mathrm{Ca}^{2+}$-abundant environment. We can conclude that $\mathrm{AMBN}$ binds $\mathrm{Ca}^{2+}$ only in its oligomeric form. This fact is demonstrated by the difference between AMBN ISO I, AMBN ISO II, and the apparently monomeric form of AMBN form lacking the exon 5 (AMBN del E5) and C-terminal part of AMBN (AMBN-Cterm). Both monomeric forms of AMBN (AMBN del E5 and AMBN-Cterm) do not bind to $\mathrm{Ca}^{2+}$.

Contrary to our expectations, $\mathrm{Ca}^{2+}$ does not appear to affect the formation of secondary or tertiary structures or their stabilization. The protein remains disordered, and $\mathrm{Ca}^{2+}$ binding is probably a transient process in which $\mathrm{Ca}^{2+}$ serve as proxies for intermolecular interactions between AMBN C-termini. This is supported by the fact that these $\mathrm{Ca}^{2+}$-mediated interactions lead to a more compact conformation of oligomeric AMBN species, as evidenced by their higher observed sedimentation coefficient values in the presence of $\mathrm{Ca}^{2+}$. With all the known properties of AMBN, it can be assumed that the only events that can be expected due to differences between both isoforms may be either their different proteolytic profiles presented by proteases (MMP20 and KLK4) or a different pattern of posttranslational modifications, particularly the phosphorylation [3]. Therefore, a detailed characterization of both processes is the aim of our further study.

Supplementary Materials: The following are available online at http://www.mdpi.com/1422-0067/21/23/9293/s1.

Author Contributions: J.V. (Jiri Vondrasek) and K.B. designed the research. V.V., M.Z., L.B., O.V., P.S. and K.P. performed the experiments. V.V., M.Z., L.B., O.V., V.K., J.V. (Jiri Vymetal), J.S., M.R., T.C., J.E.R., K.B. and J.V. (Jiri Vondrasek) analysed the data. V.V., K.B. and J.V. (Jiri Vondrasek) wrote the manuscript. All authors have read and agreed to the published version of the manuscript.

Funding: This project was supported by the Institute of Organic Chemistry and Biochemistry of the Czech Academy of Sciences (RVO: 61388963) and by the European Regional Development Fund; OP RDE; Project: "ChemBioDrug" (No. CZ.02.1.01/0.0/0.0/16_019/0000729). 
Acknowledgments: We would like to thank Radek Soucek for Amino Acid Analyses and Romana Hadravova for Transmission electron microscopy from the Institute of Organic Chemistry and Biochemistry of the Czech Academy of Sciences. We acknowledge CMS-BIOCEV ("Biophysical techniques, Crystallization, Diffraction, Structural mass spectrometry") supported by MEYS CR (LM2018127).

Conflicts of Interest: The authors declare no conflict of interest.

\section{Abbreviations}

$\begin{array}{ll}\text { Ambn } & \text { Ameloblastin protein } \\ \text { AMBN } & \text { Human ameloblastin protein } \\ \text { AMBN del E5 } & \text { AMBN form lacking the exon 5 } \\ \text { AMBN ISO I } & \text { Isoform I of AMBN } \\ \text { AMBN ISO II } & \text { Isoform II of AMBN } \\ \text { AMBN-Cterm } & \text { C-terminal part of AMBN } \\ \text { AMBN-Nterm } & \text { N-terminal part of AMBN } \\ \text { Amel } & \text { Amelogenin } \\ \text { AUC } & \text { Analytical ultracentrifugation } \\ \text { BSA } & \text { Bovine serum albumin } \\ \text { BGE } & \text { Buffered background electrolyte } \\ \text { Ca2+ } & \text { Calcium ions } \\ \text { CD } & \text { Circular dichroism spectroscopy } \\ \text { CE } & \text { Capillary electrophoresis } \\ \text { D2P2 } & \text { Database of Disordered Protein Predictions } \\ \text { DLS } & \text { Dynamic light scattering } \\ \text { DMSO } & \text { Dimethylsulphoxide } \\ \text { DSF } & \text { Differential scanning fluorimetry } \\ \text { EGTA } & \text { Ethyleneglycol-bis(beta-aminoethylether)-N,N'-tetraacetic acid } \\ \text { EMPs } & \text { Extracellular matrix proteins } \\ \text { Exon 5 } & \text { Sequence encoded by exon 5 of AMBN } \\ \text { IDPs } & \text { Intrinsically disordered proteins } \\ \text { LB } & \text { Luria-Bertani broth } \\ \text { MMP20 } & \text { Enamelysin } \\ \text { PDI } & \text { Polydispersity index } \\ \text { Rh } & \text { Hydrodynamic radii } \\ \text { RS } & \text { Stokes hydrodynamic radii } \\ \text { SCPPs } & \text { Tecretory Calcium-Binding Phosphoproteins } \\ \text { SEM } & \text { Transmission electron microscopy } \\ \text { TEM } & \\ \text { TEV } & \text { Thioredoxin tag } \\ \text { Trx } & \end{array}$

\section{References}

1. Wald, T.; Bednarova, L.; Osicka, R.; Pachl, P.; Sulc, M.; Lyngstadaas, S.P.; Slaby, I.; Vondrasek, J. Biophysical characterization of recombinant human ameloblastin. Eur. J. Oral Sci. 2011, 119, 261-269. [CrossRef] [PubMed]

2. Wald, T.; Osickova, A.; Sulc, M.; Benada, O.; Semeradtova, A.; Rezabkova, L.; Veverka, V.; Bednarova, L.; Maly, J.; Macek, P.; et al. Intrinsically Disordered Enamel Matrix Protein Ameloblastin Forms Ribbon-like Supramolecular Structures via an N-terminal Segment Encoded by Exon 5. J. Biol. Chem. 2013, 288, 22333-22345. [CrossRef] [PubMed]

3. Stakkestad, O.; Lyngstadaas, S.P.; Thiede, B.; Vondrasek, J.; Skalhegg, B.S.; Reseland, J.E. Phosphorylation Modulates Ameloblastin Self-assembly and $\mathrm{Ca}^{2+}$ Binding. Front. Physiol. 2017, 8, 10. [CrossRef]

4. Boskey, A.L.; Villarreal-Ramirez, E. Intrinsically disordered proteins and biomineralization. Matrix Biol. 2016, 52-54, 43-59. [CrossRef] [PubMed] 
5. Kalmar, L.; Homola, D.; Varga, G.; Tompa, P. Structural disorder in proteins brings order to crystal growth in biomineralization. Bone 2012, 51, 528-534. [CrossRef]

6. Grzybowska, E.A. Calcium-Binding Proteins with Disordered Structure and Their Role in Secretion, Storage, and Cellular Signaling. Biomolecules 2018, 8, 42. [CrossRef]

7. Paine, M.L.; Snead, M.L. Protein Interactions During Assembly of the Enamel Organic Extracellular Matrix. J. Bone Min. Res. 1997, 12, 221-227. [CrossRef]

8. Ravindranath, H.H.; Chen, L.-S.; Zeichner-David, M.; Ishima, R.; Ravindranath, R.M.H. Interaction between the enamel matrix proteins amelogenin and ameloblastin. Biochem. Biophys. Res. Commun. 2004, 323, 1075-1083. [CrossRef]

9. Deutsch, D.; Haze-Filderman, A.; Blumenfeld, A.; Dafni, L.; Leiser, Y.; Shay, B.; Gruenbaum-Cohen, Y.; Rosenfeld, E.; Fermon, E.; Zimmermann, B. Amelogenin, a major structural protein in mineralizing enamel, is also expressed in soft tissues: Brain and cells of the hematopoietic system. Eur. J. Oral Sci. 2006, 114, 183-189. [CrossRef]

10. Deutsch, D.; Leiser, Y.; Shay, B.; Fermon, E.; Taylor, A.; Rosenfeld, E.; Dafni, L.; Charuvi, K.; Cohen, Y.; Haze, A. The human tuftelin gene and the expression of tuftelin in mineralizing and nonmineralizing tissues. Connect. Tissue Res. 2002, 43, 425-434. [CrossRef] [PubMed]

11. Hu, J.C.-C.; Hu, Y.; Lu, Y.; Smith, C.E.; Lertlam, R.; Wright, J.T.; Suggs, C.; McKee, M.D.; Beniash, E.; Kabir, M.E. Enamelin is critical for ameloblast integrity and enamel ultrastructure formation. PloS ONE 2014, 9, e89303. [CrossRef] [PubMed]

12. Lu, Y.; Papagerakis, P.; Yamakoshi, Y.; Hu, J.; Bartlett, J.; Simmer, J. Functions of KLK4 and MMP-20 in dental enamel formation. Biol. Chem. 2008, 389, 695-700. [CrossRef] [PubMed]

13. Ruff, K.M.; Roberts, S.; Chilkoti, A.; Pappu, R.V. Advances in understanding stimulus-responsive phase behavior of intrinsically disordered protein polymers. J. Mol. Biol. 2018, 430, 4619-4635. [CrossRef] [PubMed]

14. Sharma, R.; Raduly, Z.; Miskei, M.; Fuxreiter, M. Fuzzy complexes: Specific binding without complete folding. FEBS Lett. 2015, 589, 2533-2542. [CrossRef] [PubMed]

15. MacDougall, M.; Simmons, D.; Gu, T.T.; Forsman-Semb, K.; Kärrman Mårdh, C.; Mesbah, M.; Forest, N.; Krebsbach, P.H.; Yamada, Y.; Berdal, A. Cloning, characterization and immunolocalization of human ameloblastin. Eur. J. Oral Sci. 2000, 108, 303-310. [CrossRef]

16. Vymětal, J.; Slabý, I.; Spahr, A.; Vondrášek, J.; Lyngstadaas, S.P. Bioinformatic analysis and molecular modelling of human ameloblastin suggest a two-domain intrinsically unstructured calcium-binding protein. Eur. J. Oral Sci. 2008, 116, 124-134. [CrossRef]

17. Kärrman Mårdh, C.; Bäckman, B.; Simmons, D.; Golovleva, I.; Gu, T.T.; Holmgren, G.; MacDougall, M.; Forsman-Semb, K. Human ameloblastin gene: Genomic organization and mutation analysis in amelogenesis imperfecta patients. Eur. J. Oral Sci. 2001, 109, 8-13. [CrossRef]

18. Putnam, C. PROTEIN CALCULATOR v3.4; The Scripps Research Institute: La Jolla, CA, USA, 2013.

19. Simmer, J.P.; Fincham, A.G. Molecular Mechanisms of Dental Enamel Formation. Crit. Rev. Oral Biol. Med. 1995, 6, 84-108. [CrossRef]

20. Margolis, H.C.; Beniash, E.; Fowler, C.E. Role of Macromolecular Assembly of Enamel Matrix Proteins in Enamel Formation. J. Dent. Res. 2006, 85, 775-793. [CrossRef]

21. Paine, M.L.; White, S.N.; Luo, W.; Fong, H.; Sarikaya, M.; Snead, M.L. Regulated gene expression dictates enamel structure and tooth function. Matrix Biol. 2001, 20, 273-292. [CrossRef]

22. Mazumder, P.; Prajapati, S.; Lokappa, S.B.; Gallon, V.; Moradian-Oldak, J. Analysis of co-assembly and co-localization of ameloblastin and amelogenin. Front. Physiol. 2014, 5, 274. [CrossRef] [PubMed]

23. Hatakeyama, J.; Fukumoto, S.; Nakamura, T.; Haruyama, N.; Suzuki, S.; Hatakeyama, Y.; Shum, L.; Gibson, C.W.; Yamada, Y.; Kulkarni, A.B. Synergistic Roles of Amelogenin and Ameloblastin. J. Dent. Res. 2009, 88, 318-322. [CrossRef] [PubMed]

24. Su, J.; Kegulian, N.C.; Bapat, R.A.; Moradian-Oldak, J. Ameloblastin Binds to Phospholipid Bilayers via a Helix-Forming Motif within the Sequence Encoded by Exon 5. ACS Omega 2019, 4, 4405-4416. [CrossRef] [PubMed]

25. Wald, T.; Spoutil, F.; Osickova, A.; Prochazkova, M.; Benada, O.; Kasparek, P.; Bumba, L.; Klein, O.D.; Sedlacek, R.; Sebo, P.; et al. Intrinsically disordered proteins drive enamel formation via an evolutionarily conserved self-assembly motif. Proc. Natl. Acad. Sci. USA 2017, 114, E1641-E1650. [CrossRef] [PubMed] 
26. Su, J.; Chandrababu, K.B.; Moradian-Oldak, J. Ameloblastin peptide encoded by exon 5 interacts with amelogenin N-terminus. Biochem. Biophys. Rep. 2016, 7, 26-32. [CrossRef]

27. Lu, T.; Li, M.; Xu, X.; Xiong, J.; Huang, C.; Zhang, X.; Hu, A.; Peng, L.; Cai, D.; Zhang, L.; et al. Whole exome sequencing identifies an AMBN missense mutation causing severe autosomal-dominant amelogenesis imperfecta and dentin disorders. Int. J. Oral Sci. 2018, 10, 26. [CrossRef]

28. Delgado, S.; Davit-Béal, T.; Allizard, F.; Sire, J.-Y. Tooth development in a scincid lizard, Chalcides viridanus (Squamata), with particular attention to enamel formation. Cell Tissue Res. 2005, 319, 71-89. [CrossRef]

29. Delgado, S.; Casane, D.; Bonnaud, L.; Laurin, M.; Sire, J.-Y.; Girondot, M. Molecular Evidence for Precambrian Origin of Amelogenin, the Major Protein of Vertebrate Enamel. Mol. Biol. Evol. 2001, 18, 2146-2153. [CrossRef]

30. Girondot, M.; Sire, J.-Y. Evolution of the amelogenin gene in toothed and toothless vertebrates. Eur. J. Oral Sci. 1998, 106, 501-508. [CrossRef]

31. Fernàndez-Busquets, X.; Körnig, A.; Bucior, I.; Burger, M.M.; Anselmetti, D. Self-Recognition and $\mathrm{Ca}^{2+}$-Dependent Carbohydrate-Carbohydrate Cell Adhesion Provide Clues to the Cambrian Explosion. Mol. Biol. Evol. 2009, 26, 2551-2561. [CrossRef]

32. Evans, J.S. "Liquid-like" biomineralization protein assemblies: A key to the regulation of non-classical nucleation. CrystEngComm 2013, 15, 8388-8394. [CrossRef]

33. Kobayashi, K.; Yamakoshi, Y.; Hu, J.C.-C.; Gomi, K.; Arai, T.; Fukae, M.; Krebsbach, P.H.; Simmer, J.P. Splicing Determines the Glycosylation State of Ameloblastin. J. Dent. Res. 2007, 86, 962-967. [CrossRef] [PubMed]

34. Yamakoshi, Y.; Richardson, A.S.; Nunez, S.M.; Yamakoshi, F.; Milkovich, R.N.; Hu, J.C.C.; Bartlett, J.D.; Simmer, J.P. Enamel proteins and proteases in Mmp20 and Klk4 null and double-null mice. Eur. J. Oral Sci. 2011, 119, 206-216. [CrossRef] [PubMed]

35. Uversky, V.N. Intrinsically disordered proteins and their environment: Effects of strong denaturants, temperature, $\mathrm{pH}$, counter ions, membranes, binding partners, osmolytes, and macromolecular crowding. Protein J. 2009, 28, 305-325. [CrossRef] [PubMed]

36. Oates, M.E.; Romero, P.; Ishida, T.; Ghalwash, M.; Mizianty, M.J.; Xue, B.; Dosztányi, Z.; Uversky, V.N.; Obradovic, Z.; Kurgan, L.; et al. D2P2: Database of disordered protein predictions. Nucleic Acids Res. 2012, 41, D508-D516. [CrossRef]

37. Kjaergaard, M.; Nørholm, A.-B.; Hendus-Altenburger, R.; Pedersen, S.F.; Poulsen, F.M.; Kragelund, B.B. Temperature-dependent structural changes in intrinsically disordered proteins: Formation of alpha-helices or loss of polyproline II? Protein Sci. 2010, 19, 1555-1564. [CrossRef]

38. Erickson, H.P. Size and Shape of Protein Molecules at the Nanometer Level Determined by Sedimentation, Gel Filtration, and Electron Microscopy. Biol. Proced. Online 2009, 11, 32. [CrossRef]

39. Heegaard, N.H.H.; Robey, F.A. A capillary electrophoresis-based assay for the binding of $\mathrm{Ca}^{2+}$ and phosphorylcholine to human C-reactive protein. J. Immunol. Methods 1993, 166, 103-110. [CrossRef]

40. Clapham, D.E. Calcium Signaling. Cell 2007, 131, 1047-1058. [CrossRef]

41. Ikura, M. Calcium binding and conformational response in EF-hand proteins. Trends Biochem. Sci. 1996, 21, 14-17. [CrossRef]

42. Sheng, Z.-H.; Rettig, J.; Cook, T.; Catterall, W.A. Calcium-dependent interaction of N-type calcium channels with the synaptic core complex. Nature 1996, 379, 451-454. [CrossRef] [PubMed]

43. Christopeit, T.; Gossas, T.; Danielson, U.H. Characterization of $\mathrm{Ca}^{2+}$ and phosphocholine interactions with C-reactive protein using a surface plasmon resonance biosensor. Anal. Biochem. 2009, 391, 39-44. [CrossRef] [PubMed]

44. Beyeler, M.; Schild, C.; Lutz, R.; Chiquet, M.; Trueb, B. Identification of a fibronectin interaction site in the extracellular matrix protein ameloblastin. Exp. Cell Res. 2010, 316, 1202-1212. [CrossRef] [PubMed]

45. Ravindranath, R.M.; Devarajan, A.; Uchida, T. Spatiotemporal expression of ameloblastin isoforms during murine tooth development. J. Biol. Chem. 2007, 282, 36370-36376. [CrossRef]

46. Stakkestad, Ø.; Lyngstadaas, S.P.; Vondrasek, J.; Gordeladze, J.O.; Reseland, J.E. Ameloblastin peptides modulates the osteogenic capacity of human mesenchymal stem cells. Front. Physiol. 2017, 8, 58. [CrossRef]

47. Chattopadhyay, G.; Varadarajan, R. Facile measurement of protein stability and folding kinetics using a nano differential scanning fluorimeter. Protein Sci. 2019, 28, 1127-1134. [CrossRef] 
48. Rozbeský, D.; Kavan, D.; Chmelík, J.; Novák, P.; Vaněk, O.; Bezouška, K. High-level expression of soluble form of mouse natural killer cell receptor NKR-P1C (B6) in Escherichia coli. Protein Expr. Purif. 2011, 77, 178-184. [CrossRef]

49. Hayes, D.; Laue, T.; Philo, J. Program Sednterp: Sedimentation Interpretation Program; Alliance Protein Laboratories: Thousand Oaks, CA, USA, 1995.

50. Schuck, P. Size-distribution analysis of macromolecules by sedimentation velocity ultracentrifugation and lamm equation modeling. Biophys. J. 2000, 78, 1606-1619. [CrossRef]

51. Brautigam, C.A. Calculations and publication-quality illustrations for analytical ultracentrifugation data. In Methods in Enzymology; Elsevier: Amsterdam, The Netherlands, 2015; Volume 562, pp. 109-133.

52. Štěpánová, S.; Václav, K. Capillary Electrophoretic Methods Applied to the Investigation of Peptide Complexes. J. Sep. Sci. 2015, 38, 2708-2721. [CrossRef]

53. Hunter, J.D. Matplotlib: A 2D Graphics Environment. Comput. Sci. Eng. 2007, 9, 90-95. [CrossRef]

Publisher's Note: MDPI stays neutral with regard to jurisdictional claims in published maps and institutional affiliations.

(C) 2020 by the authors. Licensee MDPI, Basel, Switzerland. This article is an open access article distributed under the terms and conditions of the Creative Commons Attribution (CC BY) license (http://creativecommons.org/licenses/by/4.0/). 